\title{
Capital adequacy, ETS and investment uncertainty in the Australian power market
}

\author{
Paul Simshauser*^ \\ Chief Economist, AGL Energy Ltd \\ Level 22, 101 Miller Street \\ North Sydney, NSW, 2060. \\ July 2009
}

\begin{abstract}
Resource adequacy in the utilities industry is a well understood concept. Capital adequacy is not. Yet it has the ability to be just as destructive to resource adequacy as poor market design or regulatory failure. Ignoring the importance of capital markets risks overlooking one of the most fundamental drivers of investment and price in the utilities industry. The fact that energy utilities are the $3^{\text {rd }}$ largest users of debt capital, behind Governments and Banks respectively, only serves to underline this point. While the worst effects of the financial crisis are beginning to subside, the residual fallout will be more than a passing fad for energy utilities.
\end{abstract}

\section{Introduction}

Australian energy utilities have an existing asset stock of US $\$ 100$ billion, but more importantly a further US\$70 billion needs to be invested between now and 2020; US\$26 billion of which will flow into additional power generating capacity. These investment requirements are large by Australian standards, let alone its relativity to the existing utilities asset base that has been built up over many decades. At the time of writing however, investment uncertainty in Australia's National Electricity Market (NEM) had reached an all-time high. Never have so many looming issues existed contemporaneously. Some issues are common to all power systems around the world such as the financial crisis and a requirement for substantial new plant capacity. Others such as our structural reliance on foreign capital and an emissions trading scheme (ETS) caught in a political crossfire, are more specific to Australia.

Resource adequacy, that is, the ability of deregulated energy-only power markets to deliver investments to meet demand in a timely manner, is a relatively well understood concept in energy industry circles. Capital adequacy is not. Yet it has the ability to be just as destructive to resource adequacy as poor market design or regulatory failure. To put this into context, the global economic cycle which sent economies spiraling downwards from 2008 occurred with little warning from economists. The reason for this is simple; the crisis commenced in the capital markets (i.e. as a financial crisis) but finance occupies at best a peripheral position in mainstream economics. Economists tend focus on the usual thematics of demand, supply, consumption patterns and so on. Making the link between financial markets and the real economy has certainly not been the focus of mainstream research.

The most severe effects of the financial crisis appear to be subsiding, but the residual fallout will not be a passing fad. The tenor, cost and availability of debt capital has fundamentally changed and energy utilities, policymakers, and regulators alike will need a much deeper understanding of how these changed conditions will impact future investment in, and the prices of, electricity. The reason for this should be abundantly clear. On the east-coast of Australia for example, 65\%

* Paul Simshauser is also Professor of Finance at Griffith University's Business School. The views expressed in this paper are those of the author and not necessarily those of AGL Energy Ltd.

^ I am indebted to Claus Larsen (AGL Energy Ltd) for his invaluable assistance in compiling the capital markets data contained in this research. I am also grateful for the peer review of this article by Thao Doan (Stanwell Corporation), Vijendra Satkunasignham (ANZ Bank), Craig Rogers (Malleson Stephen Jacques Lawyers), Tim Nelson (AGL Energy Ltd) and Robert Ludecke (BNP Paribas). Any errors or omissions remain entirely the responsibility of the author. 
of the wholesale cost of power is driven by the capital cost and the cost of capital of power stations. Accordingly, ignoring the importance of capital markets overlooks one of the most fundamental drivers of investment and price in our industry. Yet as with mainstream economics, capital markets occupy at best a peripheral position in energy economic research. Thus is the objective of this paper.

This paper is structured as follows; Section 2 discusses key drivers of investment uncertainty in Australia's NEM. Section 3 presents a quantitative analysis of resource adequacy in the NEM. Section 4 then discusses the notion of capital adequacy and presents key capital markets data. Section 5 follows with an analysis of the NEM's 'base load dilemma'. Policy implications and conclusions follow.

\section{Key drivers of investment uncertainty in the NEM}

The so-called Global Financial Crisis began to impact the real economy in Australia by mid2008. While the collapse of the Collateralized Debt Obligation (CDO) market in late-2007 had a more immediate impact on the US and the UK, Australian bank exposures to this market were minimal and so too, therefore, was the fallout in the Australian economy. But as this paper later reveals, Australia's structural reliance on foreign capital would eventually import its adverse effects. The collapse of Lehman Brothers merely served to ensure this result. Unsurprisingly, Greenfield investment proposals and Mergers and Acquisitions (M\&A) activity by utilities began to plunge. But this is only part of the story. The drivers of investment uncertainty in Australia can be summarized as:

- The Financial Crisis: following the collapse of the CDO market and Lehman Brothers, the availability and tenor of debt has reduced and been materially re-priced. Corporate Australia more generally has been forced to de-leverage;

- Structural Reliance on Debt: as noted above, Australia has an acute reliance on foreign capital and this has important implications for energy utilities;

- ETS: the Federal Government announced an intention to introduce an ETS in 2008 but it is now literally in a state of suspended animation with the Bill being defeated in the Senate in August 2009. It is widely thought that some variation will eventually be passed, but the timing and format remains uncertain;

- LNG trade-effects on gas price: there are four proposals for LNG production facilities in Queensland for 2015-2018. History has shown on the West Coast of Australia that gas prices quickly calibrate from domestic cost-based prices of US\$1.75-\$2.80/GJ to international oil-parity, the so-called 'LNG net-back price' of c.US\$6.00/GJ.

\section{Resource adequacy}

In academic literature "resource adequacy" is used by energy economists to describe the potential for insufficient generating capacity relative to aggregate power system demand (Besser et al. 2002; Oren, 2003; Peluchon, 2003; Bidwell et al. 2004; Neuhoff et al. 2004; Wen et al. 2004; Bushnell, 2005; Roques et al. 2005; Simshauser, 2008). The issue is primarily one of timing, that is, will new plant capacity arrive in a timely manner? The common thematic amongst these analyses is that wholesale prices in energy-only markets are inherently unstable. As a result, consumers face the risk that power project proponents will mis-time investments, leading to transient price shocks and load shedding during the period spanning the lag in investment.

Electricity reforms in England \& Wales, Europe and the US were primarily undertaken during the 1990s in response to a common problem; a vast oversupply of generating capacity built-up 
during the pre-reform monopoly era. Australia was no different. Structural reforms and market deregulation was carried out during the 1990s in response to an oversupply of generating plant. For example, in the six years between 1979 and 1986, aggregate generating capacity in the NEM States of Queensland, New South Wales and Victoria increased by 65\% from 13,500MW to $22,250 \mathrm{MW}$, with the value of capacity stocks more than doubling, from $\$ 5.5$ billion to $\$ 12.6$ billion (Simshauser, 2006).

Table 1 sets out the plant stock as it existed in 1998 when the NEM was first formed and compares this to 'system optimal conditions'. The optimal result has been produced by a model called NEMESYS, which is a dynamic, partial equilibrium model of the NEM power system with half-hourly resolution and price formation based on a uniform, first price auction consistent with the NEM design. The model specifications have been detailed in Simshauser (2008) and accordingly will not be reproduced here.

Aggregate actual supply is 33,200MW in Table 1, which represented a 33\% reserve plant margin over peak demand of 24,970MW, some 5100MW above optimal system requirements. Note also that base load plant was materially 'overweight' by 4100MW relative to optimum. Using 2009\$ template replacement cost estimates ${ }^{1}$, the actual plant stock represents an investment of US\$25.4 billion (after depreciation is accounted for) which is US $\$ 4.0$ billion (19\%) above optimality.

Table 1: $\quad$ Optimal plant mix at NEM commencement in 1998

\begin{tabular}{|l|r|r|r|c|}
\hline Operating Duty & Optimal & Actual & Imbalance & Weighting \\
\hline (Peak load: 24,970MW) & $(\mathrm{MW})$ & $(\mathrm{MW})$ & $(\mathrm{MW})$ & \\
\hline Base Load Plant & 20,400 & 24,500 & 4,100 & overweight \\
\hline Intermediate Plant & 1,900 & 2,100 & 200 & overweight \\
\hline Peak Load Plant & 5,800 & 6,600 & 800 & overweight \\
\hline Aggregate Supply & 28,100 & 33,200 & 5,100 & oversupplied \\
\hline Capital Stock (US\$M) & $\$ 21,388.8$ & $\$ 25,433.6$ & $\$ 4,044.8$ & overcapitalised \\
\hline
\end{tabular}

References to the literature at the start of Section 4 tend to indicate that resource adequacy became a 'live issue' from 2002 onwards. Peluchon (2003) noted in the case of Europe, and Roques et al. (2005) noted in the case of England \& Wales, that resource adequacy was a relatively new problem because deregulated energy-only markets had thrived on their inheritance of generation capacity oversupply built up by the public monopolies that previously existed. And Table 1 highlights that Australia's NEM was no exception. Roques et al. (2005) noted quite accurately that there has been insufficient experience with deregulated energy-only markets to conclude that investment will be timely and adequate given the starting blocks these newly formed markets inherited. But more importantly, Roques et al. (2005) noted that the world's electricity markets are only just beginning to approach their first major 'investment cycle' - as surplus capacity from the pre-reform era is finally being absorbed (not least incremental new investments driven by renewable and greenhouse policies). Once again, Australia's NEM is a case in point. Table 2 sets out the NEM plant stock in 2008 against system optimal conditions.

\footnotetext{
${ }^{1}$ In this article, the fully developed overnight capital cost of plant will be valued in $2009 \$$ using $\$ 1760 / \mathrm{kW}$ for base load coal plant, $\$ 1200 / \mathrm{kW}$ for intermediate Combined Cycle Gas Turbine (CCGT) Plant and \$790/kW for peaking Open Cycle Gas Turbine (OCGT) plant, and will be referred to hereafter as the '2009\$ template replacement cost estimates'.
} 
Table 2: $\quad$ Optimal plant mix for the NEM in FY09

\begin{tabular}{|l|r|r|r|c|}
\hline Operating Duty & $\begin{array}{r}\text { Optimal } \\
\text { (Peak load: 35,700Mw) }\end{array}$ & Actual & Imbalance & Weighting \\
\hline Base Load Plant & 25,000 & 26,700 & 1,700 & overweight \\
\hline Intermediate Plant & 3,600 & 5,900 & 2,300 & overweight \\
\hline Peak Load Plant & 11,600 & 9,900 & $-1,700$ & underweight \\
\hline Renewables & 1,700 & 1,700 & 0 & Balanced \\
\hline Embedded Generation & 1,000 & 1,000 & 0 & Balanced \\
\hline Aggregate Supply & 42,900 & 45,300 & 2,400 & oversupplied \\
\hline Capital Stock (US\$M) & $\$ 38,817.0$ & $\$ 41,570.5$ & $\$ 2,753.5$ & overcapitalised \\
\hline
\end{tabular}

The NEM system is now oversupplied by just 2400MW with aggregate supply of 45,300MW representing an $18 \%$ reserve plant margin over peak demand of 35,700MW - an oversupply of 2400MW. Interestingly, peak load in the NEM increased by 2400MW during FY09. Using the 2009\$ template replacement cost estimates, the 45,300MW NEM plant stock represents an investment of about US\$38.8 billion and is now only US\$2.8 billion (or 6.6\%) over-capitalized relative to system optimal conditions.

One of the interesting characteristics of the literature on resource adequacy has been the focus on market design as the source of the problem. Arguments generally draw on Bushnell's (2005) much cited 'missing money theory' - that is, given the political economy of electricity prices with artificially low market price caps and a reliability of supply constraint, equilibria in energyonly markets do not cover average costs of the power station fleet under conditions of intense competition. In fact, as Bidwell and Henney (2004) observed, competitive energy-only markets are only remunerative if the power grid is virtually on the edge of collapse.

There is indeed sound economic logic behind the missing money theory and the Australian case has been well documented in Simshauser (2008). But as an author who has prosecuted the missing money theory, I find it difficult to argue that the inability to bank power projects in a timely manner is entirely due to market design and regulatory settings. ${ }^{2}$ A careful examination of events in deregulated markets as the literature on resource adequacy began to stream into academic journals reveals that the issue is indeed broader than market design. In the Australian case, it is clear from Table 1 that the NEM started with a severe structural imbalance on the supply-side in 1998, with base plant vastly overweight and in the event such plant set prices too low, too often. In England \& Wales, for similar reasons and a counterparty default, the 4000MW Drax Power Station ${ }^{3}$ went into financial distress during FY03. This happens to coincide with the surge in academic papers questioning the ability of merchant power markets to 'bank' new power plant. Although oddly enough, the literature did not make the connection between the collapse of Drax and the inability to raise cost effective project finance for new plant in England \& Wales. For example, Roques et al. (2005) noted that raising funds had become a material obstacle to building new generating plant in the England and Wales market, with "bankers extremely reluctant to engage in merchant power projects". But they stopped short of making the link between a major case in distress and the consequential impact on capital markets.

Similarly, in the case of the US, FY03 coincides with the collapse of Enron, Dynergy and the Bankruptcy filings of NRG and others. Again in the literature, the contagion that these

\footnotetext{
${ }^{2}$ One condition that limits the efficacy of the missing money theory is the transient exercise of generator market power (albeit with fragile equilibria). Certainly, the NEM has demonstrated periods of remunerative pricing over its 10 year history without a heavy reliance of market price cap events, but in truth, not with any real consistency.

3 AES Corporation walked away from their Drax Power Station acquisition in the UK after four years of operations. The 4000MW Drax coal-fired power station in the UK was initially purchased by AES Corporation (a US-based Independent Power Producer) in 1999 for $£ 1.87$ billion. Due to structural and regulatory changes to the England \& Wales electricity market rules, power prices dropped significantly and the plant went into financial distress in 2002.
} 
significant liquidity events could have on forward investments was not raised. Solutions in resource adequacy literature on both sides of the Atlantic and Australia tended to focus on changes to market rules or a reversal of retail contestability in order to reduce cash flow volatility, thus enhancing the bankability of new plant. The effects of the structure of the supplyside, financial distress and its logical impact of re-rating the cost of new entry through higher costs of capital and financing covenants, appears to have been overlooked or has been assumed to be a source problem rather than an outcome of market conditions. ${ }^{4}$

Taking the Drax distress as a regional example, the issue is that as the project finance facilities of the massive power station went into default, the credit appetite of project banks shrank overnight and interestingly, some Australian Banks with exposures to the failed England \& Wales power station project financing have since withdrawn from the British and Euro-power markets altogether. For those project banks that remained active in England \& Wales, it would hardly be contentious to suggest that their loan covenants, debt sizing criteria and risk tolerances to uncertain market outcomes were materially tightened, thus making the task of future power project financings all the more difficult. It may well be that adverse financing conditions were as least as material as price uncertainty in energy-only markets. So how would these conditions be overcome? Good power projects will always be banked, but if credit thresholds are rising, so too must the electricity price to make projects bankable. Thus, maybe it is the case that as energy industry researchers, regulators and policymakers, we and need to accept that risk in our industry had been historically and systematically mis-priced by debt and equity investors.

\section{Capital adequacy}

The energy industry is characterized by the capital intensive nature of the asset stock. In fact, the energy industry is by far and away the worlds' largest, and also the most capital intensive. This has important ramifications. Samuelson (2009) noted that one of the intriguing subplots of the global financial crisis was the complete failure of the roughly 13,000 economists in the US to predict it. At the time, most economists were focused on inflationary pressures and an overheating global economy. This crisis originated in the capital markets, but financial economics occupies at best a peripheral position in mainstream economics. Similarly in energy market economics, with $65 \%$ of wholesale electricity prices being driven by capital costs and the cost of capital, ignoring the importance of the capital markets overlooks one of the most fundamental drivers of investment and price in our industry.

EAA (2009) noted that the World Energy Council ${ }^{5}$ raised the issue of global capital adequacy as a potential risk to the energy sector's investment task back in 1995 in the absence of a financial crisis. A key issue for Australia is its' structural reliance on foreign capital due to low household savings rates and the capital intensive nature of the economy ${ }^{6}-$ an issue which also characterizes the US economy. Why this should be of particular concern to Australia (and the US) is that energy utilities are the third largest users of debt capital in the world, following Government and Banks respectively (Smith, 2008).

Unlike the US, the Australian economy has proved remarkably resilient in the 2008-2009 financial and economic crisis and has quite literally avoided a recession. As Appendix I notes, Australia is the only OECD nation that managed to register positive economic growth during FY09. But Australia's structural reliance on foreign capital had the effect of importing adverse

\footnotetext{
${ }^{4}$ See for example Bidwell and Henney (2004), Bidwell (2005) and especially de Vries (2003), Neuhoff and de Vries (2004), Roques, Newbery and Nuttall (2005).

${ }^{5}$ World Energy Council, (1997), "Financing the global energy sector - the task ahead”, WEC Publication, London. At the time, the research concluded sufficient capital would be available.

${ }^{6}$ Cornell and Drummond (2009) noted Australia has an above-average proportion of capital intensive industries (e.g. energy, utilities and mining) and a small population of about 20 million spread over a large area and hence an above average requirement for capitalintensive transport and distribution infrastructure.
} 
economic conditions via falling global liquidity. The impact of this can be far reaching. The Edison Electric Institute (2009) framed the obvious issue:

As the industry enters this period of historic capital investment, it confronts two separate but inter-related challenges; first the industry's financial and credit strength is substantially lower; second, capital markets are in turmoil, with unprecedented volatility negatively impacting the availability, terms and cost of capital...

Indeed, EAA (2009) noted that the number of active project finance banks in Australia, which have financed the overwhelming majority of power deals, had reduced from $30+$ to less than 10 . In addition, deals once underwritten by two or three banks are now being financed on a club basis with reduced holds, and tenors for project financings in Australia had reduced from 10-15 years to just 5 years. And unsurprisingly, margins had increased from about 120 basis points (bps) to 350-400bps. These results are consistent with those in Simshauser (2009) and thus that envisaged by the Edison Electric Institute (2009) certainly appears to be occurring in Australia.

It is useful to examine the capital markets data to fully appreciate the extent of the problem facing Australia's NEM. Figure 1 presents foreign capital flows for the Australian economy between 2001 and 2008. The bar chart stacks the equity and debt capital flows, which total US\$655 billion over the eight year period. The line chart, measured on the right-hand-side yaxis, illustrates capital inflows as a proportion of aggregate Australian investment. Note that from 2006-2008 aggregate foreign capital comprised 61\% of all capital funding, but critically, it is declining in line with global economic conditions, from $67 \%$ to $55 \%$.

Figure 1: Australian foreign capital flows (2001-2008)

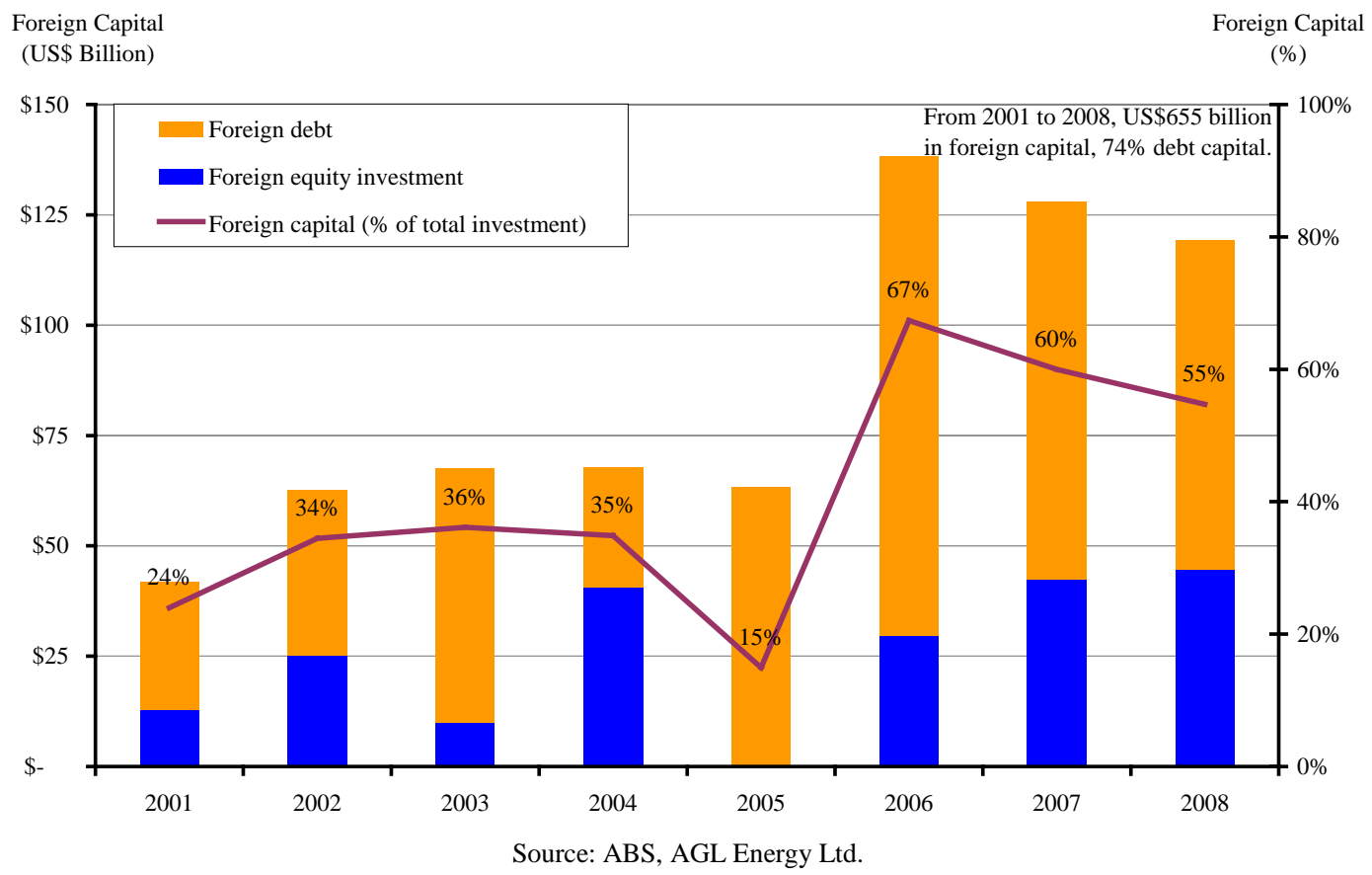

The data in Figure 1 is put into context with global Debt Capital Markets issuance in Table 3. Two key global events, the collapse of the CDO market in Q307 and the collapse of Lehman Brothers in Q308, the latter causing the inter-bank lending market to freeze-up, are highlighted in grey. Note in particular the rapid deceleration in Quarter-on-Quarter (QoQ) debt issuance and in particular, the drop in issuance from US\$857.8 billion in Q207 to just $\$ 177.8$ billion by Q308. 
Table 3: $\quad$ Global Debt Capital Markets issuance 2005-2009

\begin{tabular}{|c|c|c|c|c|c|c|c|c|c|}
\hline Year & $\begin{array}{c}2005 \\
\text { (US\$M) } \\
\end{array}$ & $\begin{array}{c}2006 \\
\text { (US\$M) } \\
\end{array}$ & $\begin{array}{l}\text { (\%chg } \\
\text { QoQ) }\end{array}$ & $\begin{array}{c}2007 \\
\text { (US\$M) } \\
\end{array}$ & $\begin{array}{l}\text { (\%chg } \\
\text { QoQ) }\end{array}$ & $\begin{array}{c}2008 \\
\text { (US\$M) }\end{array}$ & $\begin{array}{l}\text { (\%chg } \\
\text { QoQ) }\end{array}$ & $\begin{array}{c}2009 \\
\text { (US\$M) }\end{array}$ & $\begin{array}{l}\text { (\%chg } \\
\text { QoQ) }\end{array}$ \\
\hline First Quarter & 312,257 & 693,475 & 122 & 938,200 & 35 & 303,757 & -68 & 415,083 & 37 \\
\hline Second Quarter & 330,255 & 675,703 & 105 & 857,776 & 27 & 518,256 & -40 & 366,898 & -29 \\
\hline Third Quarter & 354,444 & 634,308 & 79 & 431,663 & -32 & 177,823 & -59 & & \\
\hline Fourth Quarter & 242,359 & 845,186 & 249 & 299,968 & -65 & 234,112 & -22 & & \\
\hline Total & $1,239,315$ & $2,848,672$ & 130 & $2,527,607$ & -11 & $1,233,948$ & -51 & 781,981 & -5 \\
\hline
\end{tabular}

Source: Deutsche Bank AG, Sydney (Debt Capital Markets Division)

But global syndicated loans provides the most compelling data, given that more than $95 \%$ of power project financings in Australia are initiated in this market. This is illustrated in Figure 2. The effects of the CDO collapse did not become apparent with syndication volumes until Q108 a natural consequence of the lag that occurs between initial loan commitment and the subsequent syndication process. But with world markets focused on rapidly deteriorating conditions, the impact of the Lehman collapse was virtually instantaneous.

Figure 2: $\quad$ Global syndicated loans 2004-2009

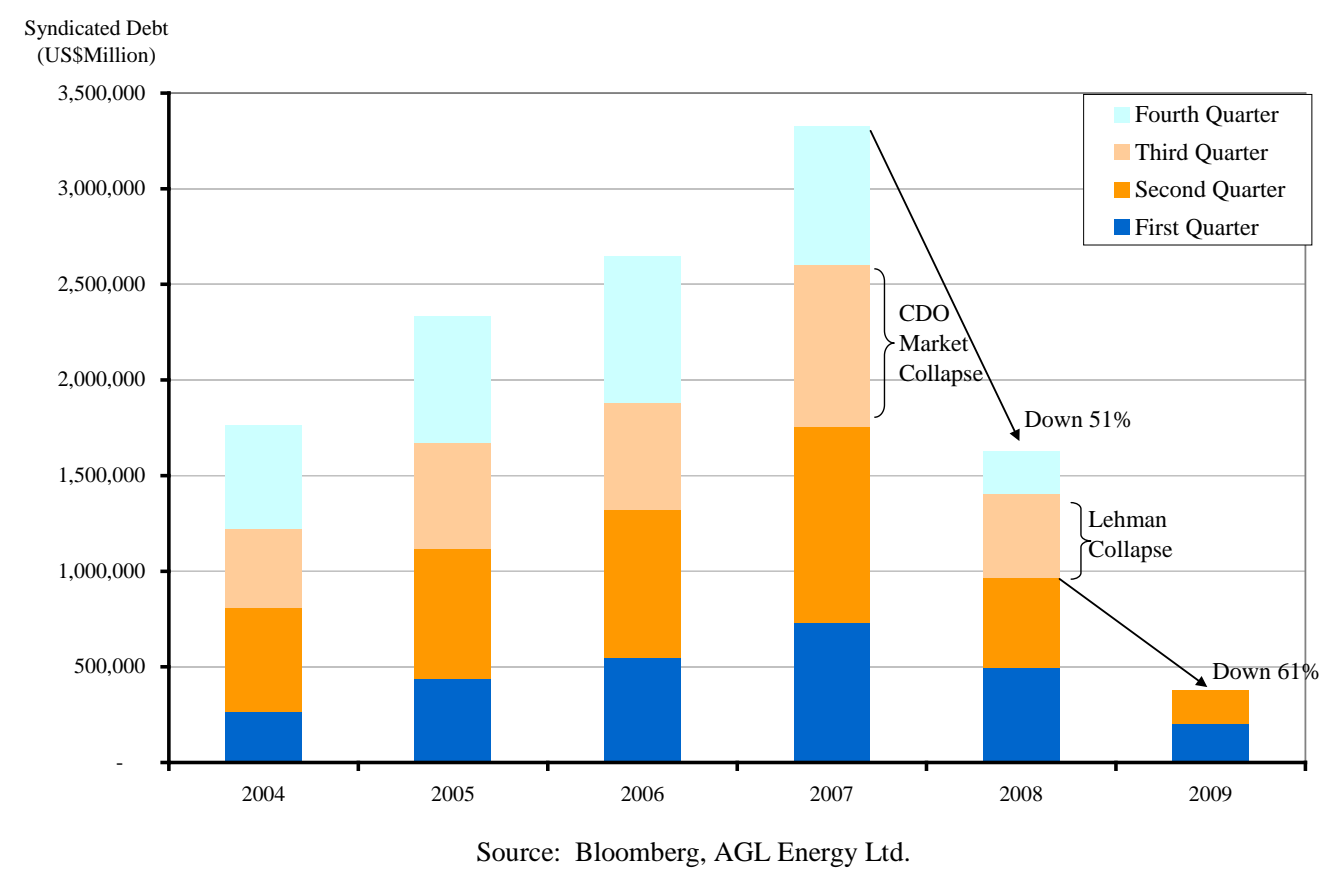

Figure 2 reveals that 2008 debt syndications of US\$1.6 trillion were down 51\% on the year prior, and $1 \mathrm{H} 2009$ was down $61 \%$ on the equivalent $1 \mathrm{H} 2008$ result. The manner in which Corporate Australia dealt with these conditions was to tap Equity Capital Markets (ECM) harder than ever before, as illustrated in Figure 3. Figure 3 provides a 20-year history of ECM raisings and highlights that US $\$ 72$ billion was raised during FY09 with very little of this being by way of Initial Public Offering. The majority is comprised of 'secondary raisings' and was primarily used to repay debt. ECM raisings represented $8.4 \%$ of the Australian stock market capitalization - and at US\$72 billion was the world's $3^{\text {rd }}$ largest equity issuance by country for FY09, behind the US and UK respectively. 
Figure 3: ASX Equity Capital Market raisings (1990-2009)

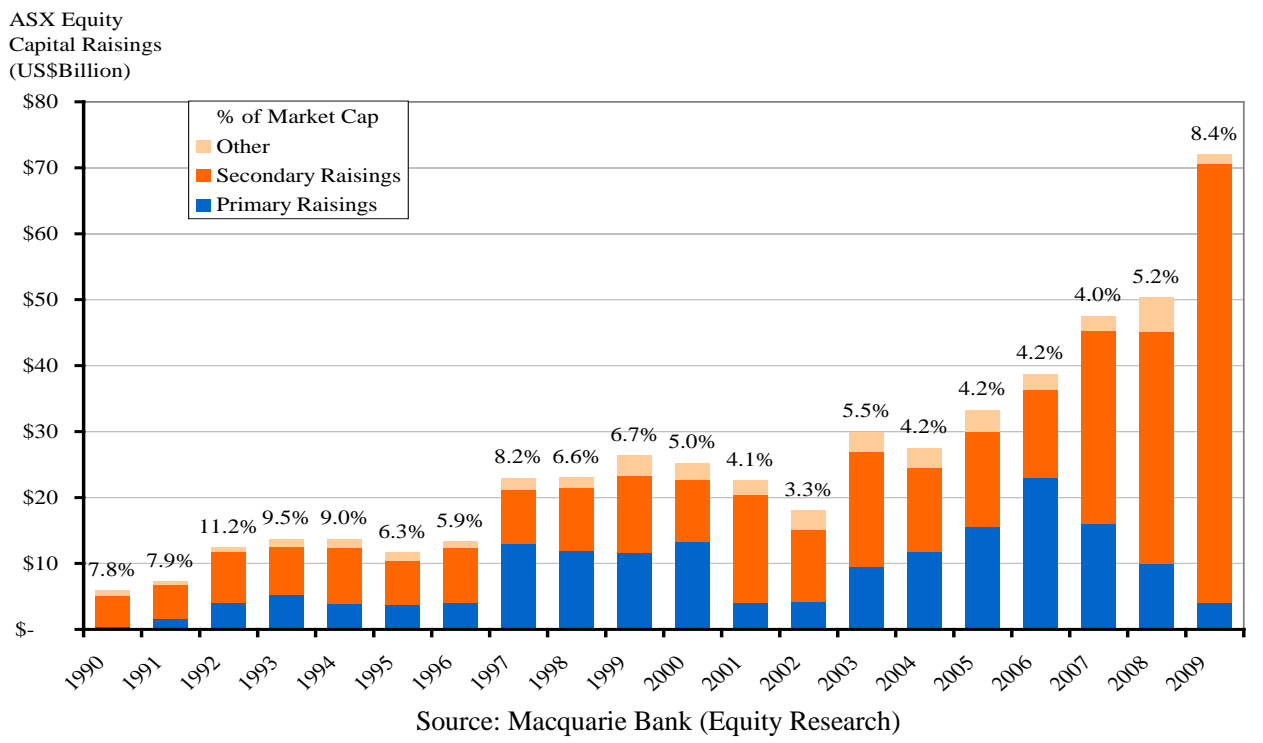

The consequence of the debt and ECM data flow is predictable; while official interest rates plunged in response to broader economic impacts, credit spreads (i.e. the profit margin applied by debt providers to underlying rates) rose sharply. Figure 4 notes that 10 -year bonds and swaps initially followed cash rates down after the collapse of Lehman, before rising at the end of the time-series as it became clear that Australia averted the worst effects of the current economic cycle. But the most spectacular data in Figure 4 are the corporate spreads, referenced against 3year BBB corporate money as the proxy. Corporate spreads had historically traded between 30100bps until the impact of the CDO collapse. Thereafter the run-up was remarkable. At the time of writing, spreads were beginning to stabilize at around 500bps. The compounding effect of this on the calculated cost of capital for a Merchant Utility, measured on the right-hand-side y-axis, is clear - rising from its low point of $10.6 \%$ to $12 \%$ on a pre-tax, nominal basis. ${ }^{7}$

Figure 4: Interest rates and spread costs (2000-2009)

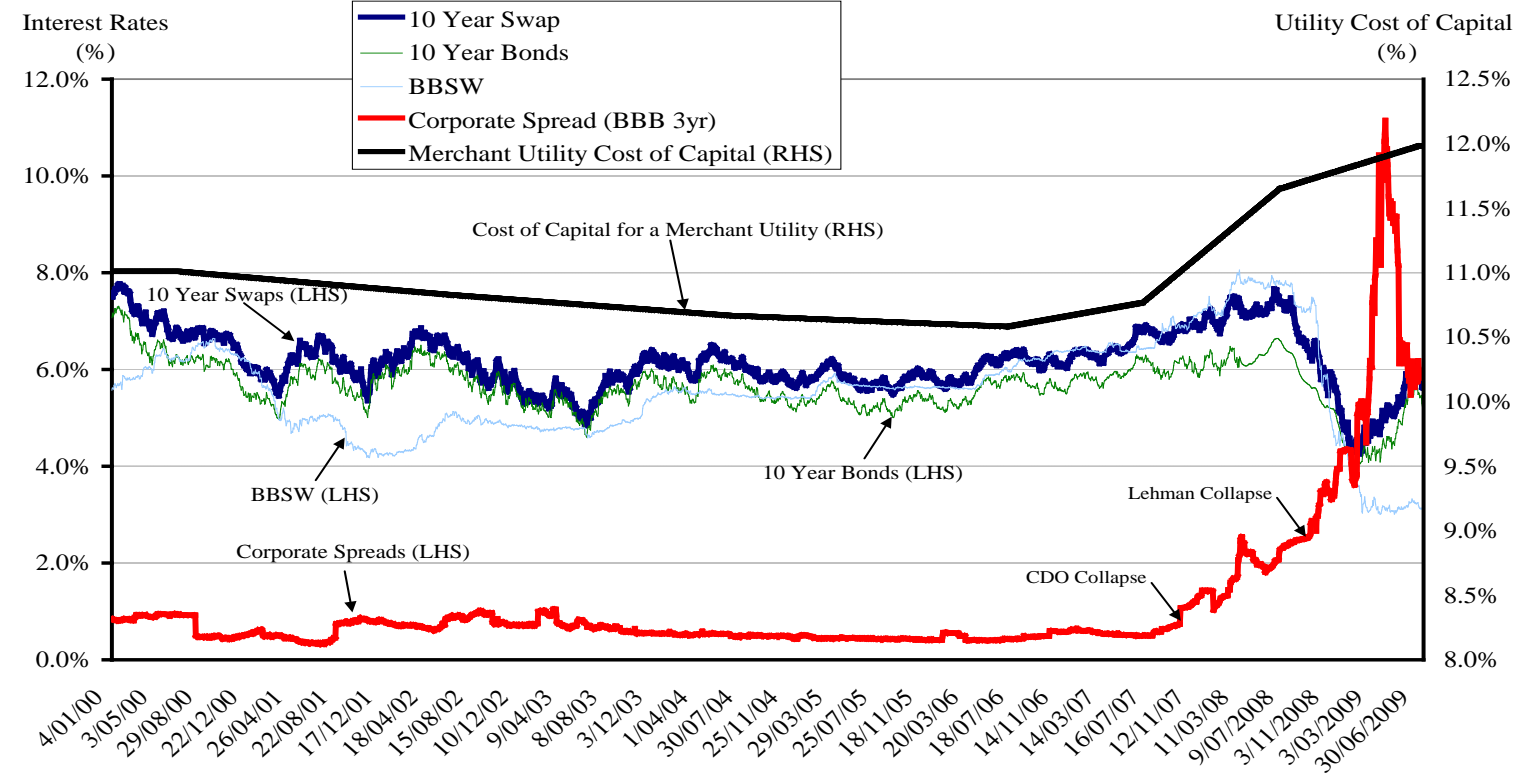

${ }^{7}$ The Capital Asset Pricing Model was used to price utility equity costs, with 10-year swaps and an assumed project finance margin of 350bps used for debt pricing (nb. project finance margins have tended to trade in the range of 350-400bps given the asset-backed nature of such financings). Debt gearing is assumed to be $65 \%$ of the asset value. 
The impact on wholesale electricity prices in Australia from the shift in the cost of capital combined with rising capital costs was examined in Simshauser, Molyneux and Shepherd (2010). In this analysis, system average cost was shown to have increased from US\$36/MWh to US $\$ 48 /$ MWh (31.5\%) in real terms between 2004 and 2009, with capital-related costs comprising $65 \%$ of total cost. Rising plant capital costs accounted for $70.5 \%$ of the $\$ 15$ increase $^{8}$, but significantly, $25.7 \%$ of the cost increase was directly attributable to deteriorating capital market conditions. System running costs changed only marginally, by 3.8\%. Ironically, and despite all of the data presented in Section 4, in 2009 the Australian Energy Regulator (using the Capital Asset Pricing Model) actually decreased the regulated weighted average cost of capital for monopoly network utility businesses, the impact of which will become clearer over the next 2-5 years. Needless to say - in the backdrop of a global financial crisis, energy utilities and institutional investors were literally stunned.

With the financial and economic crisis in full swing during 2008, it is not entirely surprising to find that investment in the energy sector slowed very materially. A useful guide to this, apart from traditional Greenfields project commitments, is global M\&A deal data, which is presented in Figure 5.

Figure 5: Global Utilities M\&A data - 2003 to 2008

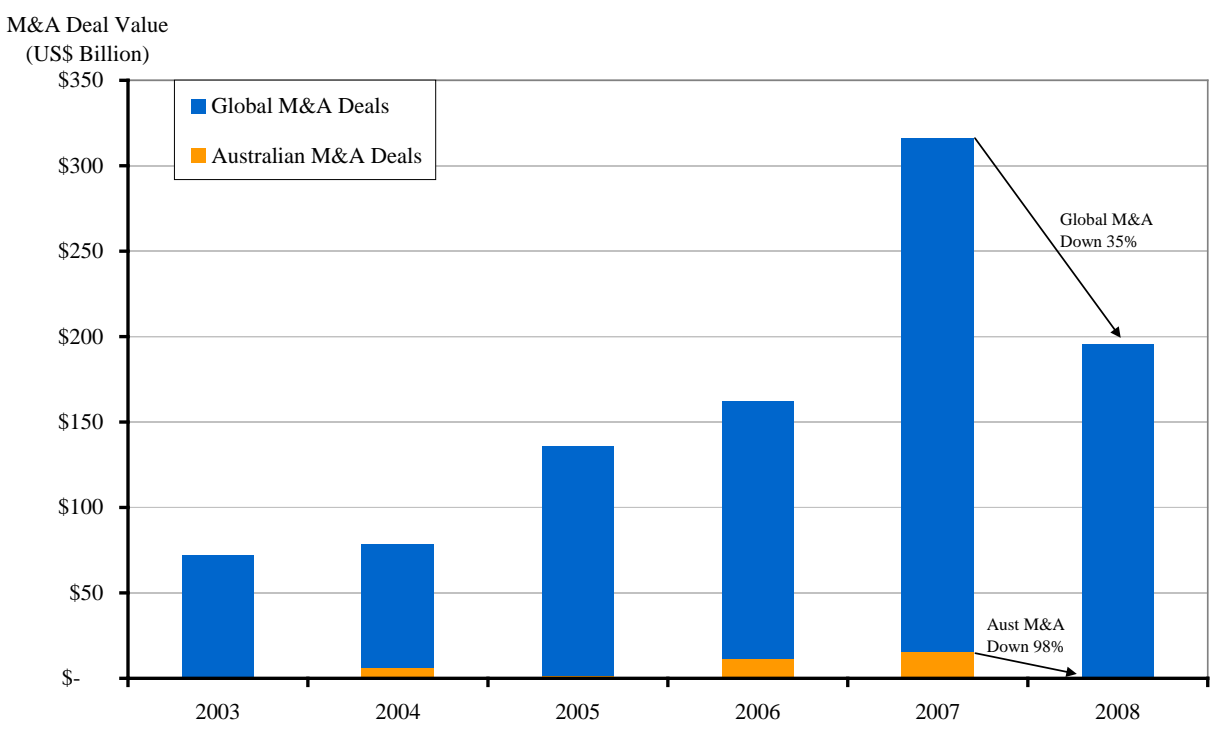

Source: Bloomberg, AGL Energy Ltd.

Note the drop in global utilities M\&A turnover from US\$316 billion in 2007 to US\$195 billion in 2008, a reduction of 35\%. But a surprising result is the Australian M\&A subset, which fell from US $\$ 16$ billion or $5 \%$ of global M\&A activity, to less than $\$ 0.5$ billion, a reduction of $98 \%$. Australia's structural reliance on foreign capital will have played a part in this with many foreign banks retreating to their home markets. But this cannot explain such a material drop relative to global markets. The underlying driver of this sharp reduction is more likely to be the combined effects of the financial crisis and the 'announced, but yet to be legislated' ETS - the latter making investment extremely complex to navigate.

\footnotetext{
${ }^{8}$ These results for Australian plant capital costs are largely consistent with those in the US. See for example CERA at http://www.cera.com/aspx/cda/public1/news/pressReleases/pressReleaseDetails.aspx?CID=10429
} 
From the above data it seems clear enough that hurdle rates for power projects have lifted from their historic lows, at a time when the price of equipment remains markedly higher than all prior periods. But in Australia, there is an additional concern, the base load dilemma. Recall from Table 2 (above) that base plant was 'overweight' by 1700MW. Considerable investment in peaking and renewable energy capacity will be required in order to ensure resource adequacy and environmental policy objectives are met. And the general view within the industry is that the next installment of base load plant is not actually required prior to 2015 - but this means planning and commitment must be made over the course of the next few years given lead order and construction lags.

\section{The base load dilemma: accounting for ETS and LNG}

Historically, the economics of energy-only markets and particularly the NEM has tended to favour base load over peaking capacity in terms of investment certainty. This is not to say that only base plant has been be financed, but rather, the task facing peaking plant power developers has been far more complex. As Peluchon (2003, p.2) noted:

...Peak capacity investment, especially, seems quite problematic. An investment in base generation plant is a decision that requires forecasting base future prices. An investment in peak generation plant is a decision that requires much more information as peak prices depend on base prices as well as from the future investments in every other kind of generation capacity. The revenue generated by peak plant is therefore much more hazardous than base plant, since it produces only when every other plant produces at full capacity or cannot produce. In the same way an option is said to be 'out-of-the-money', peak plant has a value that may change drastically with any change in the way the supply-demand balance evolves...

The quantitative evidence to support this can be drawn from a power project investment 'HitRate' analysis, which is presented below. The Energy Supply Association of Australia in its annual reports (1998-2009) has maintained an ongoing log of proposed power projects. This data has been analysed against actual commissioned plant, with Table 4 presenting the summary by technology.

Table 4: $\quad$ Hit-Rate of power projects in the NEM between 1998-2009

\begin{tabular}{lccc}
\hline $\begin{array}{l}\text { Project } \\
\text { Technology }\end{array}$ & $\begin{array}{c}\text { Number of } \\
\text { proposed projects }\end{array}$ & $\begin{array}{c}\text { Number of } \\
\text { completed projects }\end{array}$ & $\begin{array}{c}\text { Project } \\
\text { Hit-Rate }\end{array}$ \\
\hline Coal & 19 & 7 & $37 \%$ \\
CCGT & 16 & 6 & $38 \%$ \\
OCGT & 68 & 22 & $32 \%$ \\
Renewable & 76 & 27 & $36 \%$ \\
\hline NEM Total & 179 & 62 & $35 \%$ \\
\hline \multicolumn{4}{c}{}
\end{tabular}

In total, there have been 179 power projects proposed, with only 62 making it to the point of construction, an investment hit-rate of 35\%. Table 5 presents the results of the analysis by value (using the 2009\$ template replacement cost estimates) and plant capacity (MW). In all, investments totaling US\$52.4 billion and 39,335MW have been proposed, with $31.1 \%$ of the proposals being completed. In and of itself, this does not reveal a problem per se, because reliability of supply has been maintained in the NEM. 
Table 5: $\quad$ Hit-Rate of power projects in the NEM between 1998-2009 by technology

\begin{tabular}{lccccc}
\hline $\begin{array}{l}\text { Project } \\
\text { Technology }\end{array}$ & $\begin{array}{c}\text { Proposed } \\
(\mathrm{US} \$ \mathrm{M})\end{array}$ & $\begin{array}{c}\text { Completed } \\
(\mathrm{US} \$ \mathrm{M})\end{array}$ & $\begin{array}{c}\text { Proposed } \\
(\mathrm{MW})\end{array}$ & $\begin{array}{c}\text { Completed } \\
(\mathrm{MW})\end{array}$ & $\begin{array}{c}\text { Project } \\
\text { Hit-Rate }\end{array}$ \\
\hline Coal & 17,049 & 6,301 & 9,687 & 3,580 & $37.0 \%$ \\
CCGT & 9,174 & 3,236 & 7,645 & 2,697 & $35.3 \%$ \\
OCGT & 11,669 & 3,015 & 14,733 & 3,806 & $25.8 \%$ \\
Renewable & 14,540 & 4,333 & 7,270 & 2,166 & $29.8 \%$ \\
\hline NEM Total & 52,433 & 16,885 & 39,335 & 12,249 & $31.1 \%$ \\
\hline \multicolumn{5}{c}{ Source: esaa, AGL Energy Ltd. }
\end{tabular}

Note in Table 5 that the two base load technologies, Coal and Combined Cycle Gas Turbine (CCGT) plant, have a combined Hit-Rate of 36.3\% whereas the Hit-Rate for Open Cycle Gas Turbine (OCGT) peaking plant was just 25.8\%. This outcome is inconsistent with the structural analysis of the NEM supply-side in Table 2, but conversely, is entirely consistent with the missing money theory and the literature on resource adequacy, and thus not at all surprising. There are also regional differences, with the worst performing Australian state being net-power importer, New South Wales, at $11 \%$ while the best performing state is its power exporting and resource-rich neighbour, Queensland, at a 46\% project Hit-Rate.

Despite the relative historical success of base load investments, in a strange twist of irony, the emerging investment environment facing the power sector seems to have created a 'base load dilemma' because the two obvious choices for investment face almost insurmountable uncertainty at the time of writing. On the one hand, coal plant represents the lowest cost solution in the absence of an ETS because domestic thermal coal price is typically US\$20/t or US\$0.80/GJ. But with an imminent ETS and Australia's vast quantities of gas at domestic prices historically trading at US\$1.75 to US\$2.80/GJ, it creates a problem for coal plant investments as Figure 6 later reveals. On the other hand, multiple LNG terminals are being proposed in the State of Queensland from 2015-2018, and this emerging 'export capability' is thought likely to create the link between domestic gas and international oil prices for the first time on the east coast of Australia. To many countries, this may appear most unusual with gas having long been linked to oil prices. But Australia has vast endowments of very low cost, high quality coal and gas resources. Australia's coal reserves represents 43\% of the OECD and 9\% of global reserves, while Australia's gas and coal seam gas represent $21 \%$ of the OECD and $2 \%$ globally. ${ }^{9}$ This has meant that the domestic price of such resources in Australia have always been detached from world energy prices, and were thus sold at margins above cost rather than against a regional energy index, for example. The emergence of LNG plants on Australia's West Coast ultimately led to an 'LNG netback' gas price, shifting as it did from US\$1.75/GJ to about US\$6.00/GJ in the space of just 18 months between 2005 and 2007. Back to the east Australian State of Queensland, the presence of these LNG developments means the task of securing long-dated, low cost gas contracts for a post-ETS environment is a remote possibility at best (prior to 2015-2018).

In Figure 6, the cost estimates of two new entrant base load power projects, an Ultra Super Critical pulverized fuel (USCpf) and CCGT plant, are presented using a dynamic economic power plant model. This model has been described and presented in detail in Simshauser (2009) and thus its specifications will not be reproduced here - suffice to describe it as a conventional multi-year dynamic cash flow model which sizes a power station project financing given certain input parameters. The $2009 \$$ template plant cost estimates have again been used, with other key inputs being the coal price of US\$0.80/GJ and gas prices presented under three scenarios, US $\$ 2.80 / G J$ being a 'domestic cost', US\$4.50/GJ and US\$6.00/GJ representing a range of LNG netback prices, with $\$ 4.50 / G J$ representing a discount, albeit an arbitrary one, to oil prices.

\footnotetext{
${ }^{9}$ Source: Geoscience Australia, http://www.ga.gov.au/minerals/exploration/resources advice/Table1_AIMR09.jsp
} 
The single bar or 'cost stack' on the left hand side of Figure 6 represents the unit cost of an USCpf plant and is measured on the y-axis. The aggregate unit cost is about US\$39/MWh. Note that fuel and variable operations and maintenance is about US\$8/MWh, fixed running costs are about US\$5.50/MWh, debt servicing costs about US\$14/MWh and equity and taxes comprising the balance. The $\mathrm{x}$-axis provides a linear range of carbon prices. The solid line emerging from the 'cost stack' illustrates the average cost of the USCpf plant for any given carbon price assuming continuing base load operation. The three dashed lines provide the same data points for a CCGT plant with the range of unit gas prices outlined above.

Note that with no carbon price, the USCpf plant is the lowest cost plant and this explains why about $85 \%$ of Australia's electric power has historically come from coal. And unsurprisingly, the entire Australian economy has been built around these material comparative domestic energy cost advantages. At the time of writing, it is not contentious to suggest that an ETS will be on-foot in Australia within a 2-3 year window. With a 40-year investment life, and gas at 'domestic cost' (i.e. US\$2.80/GJ), an investment in USCpf plant would almost certainly lead to an accelerated case of asset stranding. Once the carbon pricing exceeds about US\$11/t the CCGT plant becomes lowest cost because its emissions intensity of $0.39 \mathrm{t} / \mathrm{MWh}$ is literally half that of an USCpf plant, at about $0.78 \mathrm{t} / \mathrm{MWh}$.

Figure 6: Long run marginal cost of base load applications in the NEM post-ETS

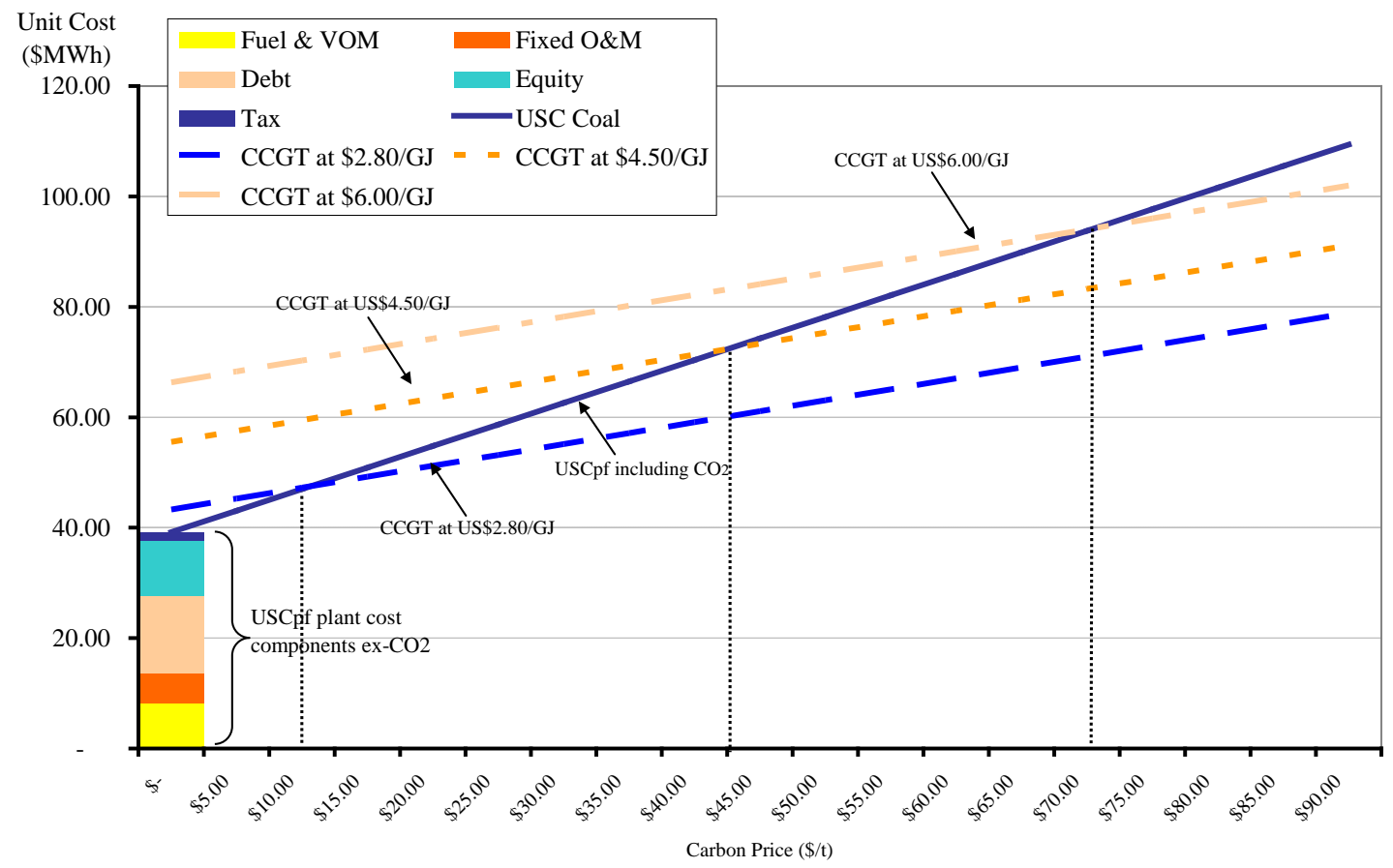

The extent to which east coast Australian gas prices shift to an 'LNG netback' price with an underlying reference to oil, is widely debated. But even the most skeptical of gas price forecasters see little prospect of sub-US\$4.50/GJ gas prices prevailing from 2015. Figure 6 notes that at these levels, the price of carbon needs to rise to about US\$40/t before the USCpf plant faces competitive pressure given the very low cost of coal, and over US\$70/t at a US\$6.00/GJ gas price.

The difficulty in pursuing an USCpf plant is that pre-financial crisis forecasts of European $\mathrm{CO}_{2}$ traded prices actually spanned the range of $\mathrm{CO}_{2}$ prices in Figure 6 above over the period 20092020. Given a 40-year investment life, this makes USCpf a complex investment task. On the other hand, at the time of writing it was simply not possible to secure a long-dated gas contract at an economic price (and arguably, at any price prior to 2015 given the enormous feedstock 
requirements of the LNG developments) ${ }^{10}$ which makes it impossible to 'bank' a CCGT plant, since project financiers in Australia have historically required security of gas price and gas supply, or a credit rated counterparty to absorb fuel price risk, before sizing project debt. Thus is the base load dilemma in Australia.

\section{Policy implications and concluding remarks}

This article has raised two key issues for the NEM; the availability and cost of capital, and the base load dilemma. From a capital availability perspective, the four major Australian Banks (i.e. National Australia Bank (NAB), Australia and New Zealand Banking Group (ANZ), Commonwealth Bank of Australia and Westpac Banking Corporation) remain well capitalized and have managed to navigate the financial crisis exceptionally well. There are only eight banks in the world with AA credit ratings or better and all four Australian banks form part of this elite group. But the Australian banks have been clear in regard to what they can contribute given prudential limitations. In a recent Australian Senate Inquiry into debt refinancings, submissions by two of the four major banks, NAB and ANZ noted:

"Refinancing risk is particularly elevated. This is compounded by the pressure of foreign banks to repatriate capital to domestic markets to shore up balance sheets eroded by losses from asset write-downs and write-offs. The four major Australian banks cannot solve the problem due to industry concentration limits and increasing capital requirements from credit quality downgrades...” (NAB Submission to the Senate Inquiry)

"Capacity is not unlimited as we are subject to regulation which establishes prudential and concentration limits. These range across industry, sector and borrower levels... (ANZ Submission to the Senate Inquiry) ${ }^{11}$

Australian savings rates are extremely low, averaging less than $1.5 \%$ of gross household income over the past five years (with a noticeable upward spike to 5\% in the Quarter following the Lehman collapse). ${ }^{12}$ Superannuation (i.e. pension) rates on the other hand are the highest in the OECD at $15.9 \%$ of Gross Domestic Product compared to the OECD average of $1.4 \%{ }^{13}$ Super contributions have more recently been accumulating at the rate of US\$96 billion per annum. ${ }^{14}$ But 'Super' fund managers tend to bias their portfolio allocations to equities and other fixed assets rather than fixed income securities. As at March 2009 for example, Super funds totaling US $\$ 700$ billion had more than 70\% allocated to equities and property, and in March 2007 this was $79 \%{ }^{15}$ The review of taxation policy, currently underway in Australia, would be well served to examine the financial incentives facing households in relation to savings, and Super fund managers in relation to asset allocation. The establishment of 'inflation-linked infrastructure bonds' with a favourable taxation treatment may entice Super funds into more domestic debt market activity, and thus would seem to be worthy of policy investigation and consideration. Naturally however, current economic conditions dictate that fiscal stimulus is an imperative for Australia in order to avoid entering a protracted recession and to that end, the tax treatment of 'voluntary' Super contributions from weekly earnings was recently degraded. But as conditions

\footnotetext{
${ }^{10}$ To put this into context, east coast gas demand is about 650PJ per annum, and 3 x 3.5Mtpa LNG terminals require about 640PJ per annum.

${ }^{11}$ Submissions to the Australian Senate Committee on Economics on the Australian Business Investment Partnership Bill (2009) by National Australia Bank (NAB) and Australia and New Zealand Banking Group (ANZ) are available at

http://www.aph.gov.au/Senate/committee/economics ctte/abip 09/submissions/sublist.htm

${ }^{12}$ Interestingly, until the late-1990s Australian savings rates were 10-15\% of disposable income. Source: Reserve Bank of Australia, Statistical Table G12.

${ }^{13}$ See OECD http://stats.oecd.org/viewhtml.aspx?QueryName=601\&QueryType=View for details of pernsion rates.

${ }^{14}$ See Australian Prudential Regulation Authority http://www.apra.gov.au/Statistics/Quarterly-Superannuation-Performance.cfm for details of Superanuation contributions in Australia.

${ }^{15}$ See Reserve Bank of Australia, Statistical Table B15 at http://www.rba.gov.au/Statistics/AlphaListing/alpha_listing_i.html for details of the asset allocation of Superannuation Funds in Australia.
} 
improve, the current review of taxation would be well served by focusing on levers available to drive further savings and voluntary Super contributions by Australian households.

Australia's domestic corporate bond market is benign, and secondary trade in such instruments is best described as shallow in depth with the market more akin to the US Private Placement Market than the deeply traded US institutional 144a market or the US SEC registered bond market. Additionally, activity in listed debt securities by retail investors in Australia remains limited, particularly by comparison to the average Australian's obsession with stock ownership. 55\% of adult Australians directly or indirectly own scrip in listed entities, which as an aside seems to be among the highest of any OECD country. ${ }^{16}$ The primary hurdle here, as with the US 144a market, is transaction cost and legal risk. To issue a corporate bond, Australian firms still need to issue a prospectus and abide by the rules of a public offer despite being under ASX continuous disclosure obligations. Thus for listed corporate Australia, it is easier, faster and usually less costly to execute an equity issue than a retail bond transaction. As one Australian bond trader said to the author in August 2009:

...It seems nonsensical to me that regulators believe I am informed enough by continuous disclosure to purchase a share in a mid-cap miner with a few clicks of a button, but at the same time I lack the information required to purchase a lower risk senior bond from the exact same entity without a prospectus and public offer. I would have thought a program system, as used in the major bond markets around the world, reliant on the continuous disclosure regime, would allow the Australian bond market to expand and provide a better source of capital to domestic borrowers. This would not only benefit investmentgrade corporates, but I think would also be of service to mid-cap corporates in Australia which are currently beholden to the commercial banks. There will be issues around investors' understanding of credit versus equity however; a requirement for a credit rating from registered providers could be included. It would be interesting to analyse how much less wealth would have been destroyed at the private investor level during the downturn if Australian retail investors had access to the facilities to enable a more balanced portfolio...

A concerted effort to drive greater liquidity by reducing debt capital transaction costs and introducing greater retail participation in the secondary market for domestic corporate bonds would therefore seem to be worthy of further policy research. But fundamentally, so long as the national savings rate remains materially below investment requirements, and given the inherent capital intensive nature of the Australian economy, a structural reliance on foreign capital will persist. Given this inevitability, the corporate tax rate should come under close scrutiny in the current review of taxation policy to ensure that Australia remains an attractive destination for the savings of other countries (with Australia's political stability, separation of powers, absence of corruption, established and trusted legal system, and robust regulatory and governance frameworks taken as given). Figure 7 illustrates OECD company tax rates in 2000 and 2008. Note that Australia's current flat tax rate of 30\% lies above the OECD average of 26\%, having dropped from $9^{\text {th }}$ to $22^{\text {nd }}$ position. Some trimming of this rate would again seem worthy of consideration in the context of national financing requirements.

\footnotetext{
${ }^{16}$ See http://www.asx.com.au/resources/pdf/international_share_ownership_summary_05.pdf for details of share ownership rates.
} 
Corporate Tax Rate

(\%)

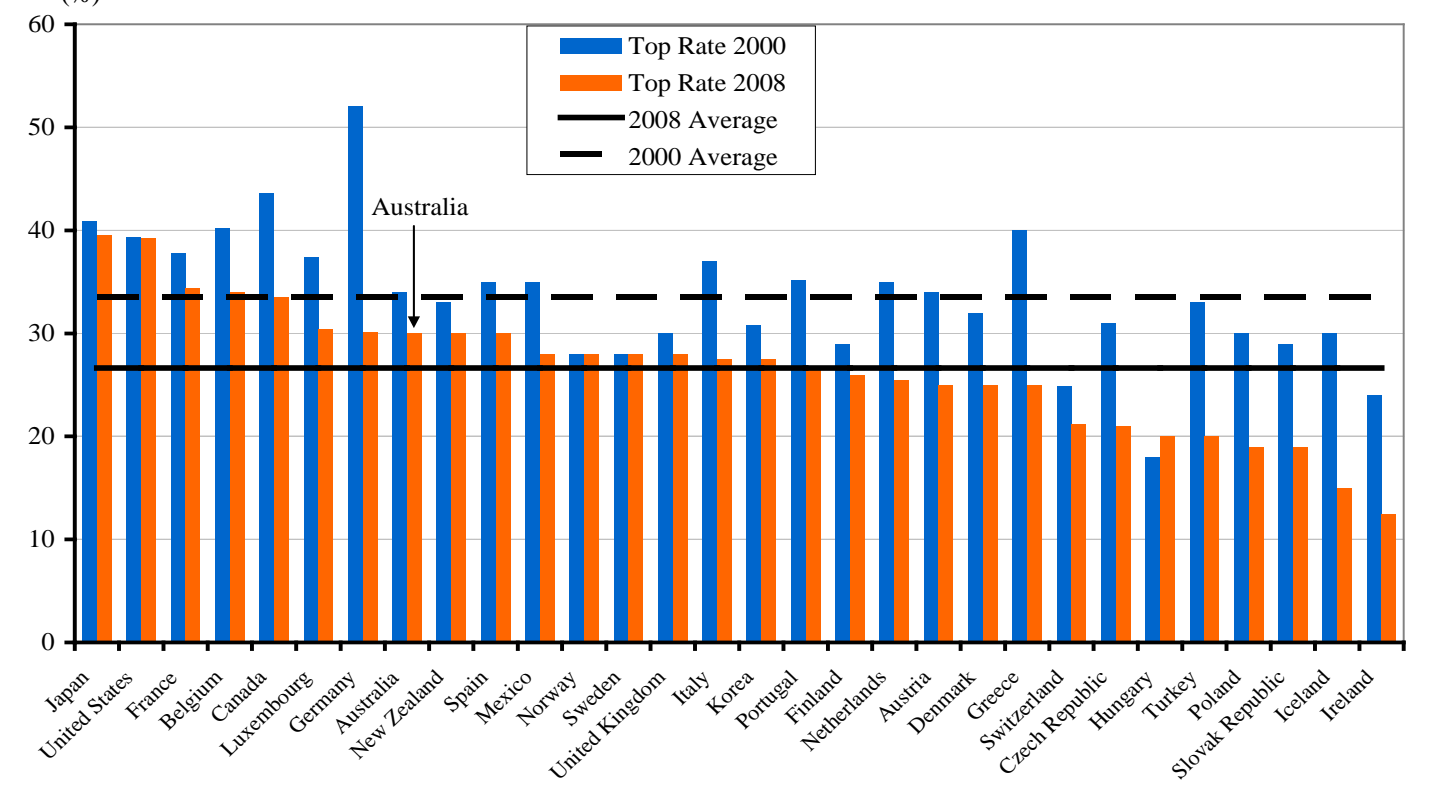

Source: OECD, AGL Energy Ltd.

From a 'cost' of capital perspective, the reality is that there is little policy makers can do, or should do. At the height of the financial crisis, the Australian Government was forced to follow the actions of other OECD governments by guaranteeing the bond issuances of the Australian banks, literally to avoid the financial meltdown of the Australian financial system. ${ }^{17}$ Despite the fact that Australia's four banks were among the most stable in the world, the lack of a federal government guarantee meant that their ability to raise funds by late-2008 following the Lehman collapse had ground to a halt because other national governments had credit-enhanced the issuance of their own domestic banks, thus putting them at a distinct advantage over the Australian banks. The Australian Government will attempt to initiate the coordinated withdrawal of sovereign guarantees at the next meeting of the Group of 20 Economies in late-2009 as capital market conditions stabilize, although evidently the US, UK and Canada have extended the original cutoff dates as their banks continue to struggle to raise funds in the absence of government support.

The credit 'wrapping' of infrastructure debt by Governments is occasionally raised as a policy option in order to lower the cost, but given the risks involved in merchant power investments (as distinct from regulated monopoly infrastructure), it is unclear why a government would guarantee the debt finance of power projects merely to 'clip' the price of power. The better view is to let markets work.

But this means the price of power in Australia will rise in line with capital market costs and other 'factor markets' that affect the end use price of power. The NEM has a fully deregulated wholesale power market and is noted as the riskiest and most volatile commodity market in the world. Yet three of the four NEM states (QLD, NSW, SA) have retained regulated retail prices, generally on 3-year price paths. Unfortunately, despite being among the most highly competitive

${ }^{17}$ Cornell \& Drummond (2009, p.60) noted that when the global financial system melted down with the collapse of Lehman in September 2009, government guarantees on deposits and bank debt were a vital emergency measure in Australia. Without them lending would have seized, with catastrophic results for the economy as Australia's four big banks became unable to access longerterm debt funding on wholesale markets, despite their AA- credit rating status. Their conclusion was clear; "While an unwelcome if untimely reassuring stress test of the system - institutions, regulators and governments - the crisis threw into stark relief this longrecognised but all too easily ignored national funding vulnerability...” 
retail electricity markets in the world, QLD and NSW have historically attempted to set an 'efficient market price' as the regulated price and on occasions, this has been set below cost with incumbent retailers bearing considerable margin erosion. Conversely, when wholesale prices have fallen any economic rent that may have been available for capture has predictably been competed away; thus is the asymmetry of attempting to set an efficient regulated price in a competitive market. Ongoing regulatory risk in this area currently remains material given the political economy of electricity prices. Deregulation of retail prices, or at least a genuine shift to regulated safety-net pricing should be considered a national policy priority, particularly given the cost shocks that will inevitably follow from an ETS and the advent of LNG net-back pricing for gas - all of which will clearly add sizeable costs to the end-use price of power. So far, only one NEM state, Victoria, has fully deregulated retail energy prices and interestingly, it is now ranked the most competitive energy market in the world. ${ }^{18}$

If we presume that power prices will not be sub-optimally regulated, policymakers should not be concerned by resource adequacy per se. There are indeed a rising number of OCGT plant proposals, many of which are finally starting to find success. I expect this trajectory to continue, albeit due entirely to the absence of less-risky alternatives owing to the emergence of the base load dilemma - the other primary issue raised in this article.

On the base load dilemma, Australia has set a 20\% Renewable Energy Target (RET). Aside from having vast coal and gas reserves, Australia also has world-class wind and solar resources. There is a large number of operating wind farms with capacity utilization factors in the $40-50 \%$ pa range. The penetration of wind, solar and other renewable technologies is forecast to expand significantly, as Figure 8 notes. Figure 8 presents two forecasts of the requirement for new generating plant in the NEM between 2009 and 2020. The left-hand bar presents a 2006 forecast view, when the RET was just 2\%. The right-hand bar presents a 2008 view, with an expanded $20 \%$ RET.

Figure 8: Forecast of generation plant from 2009 to 2020

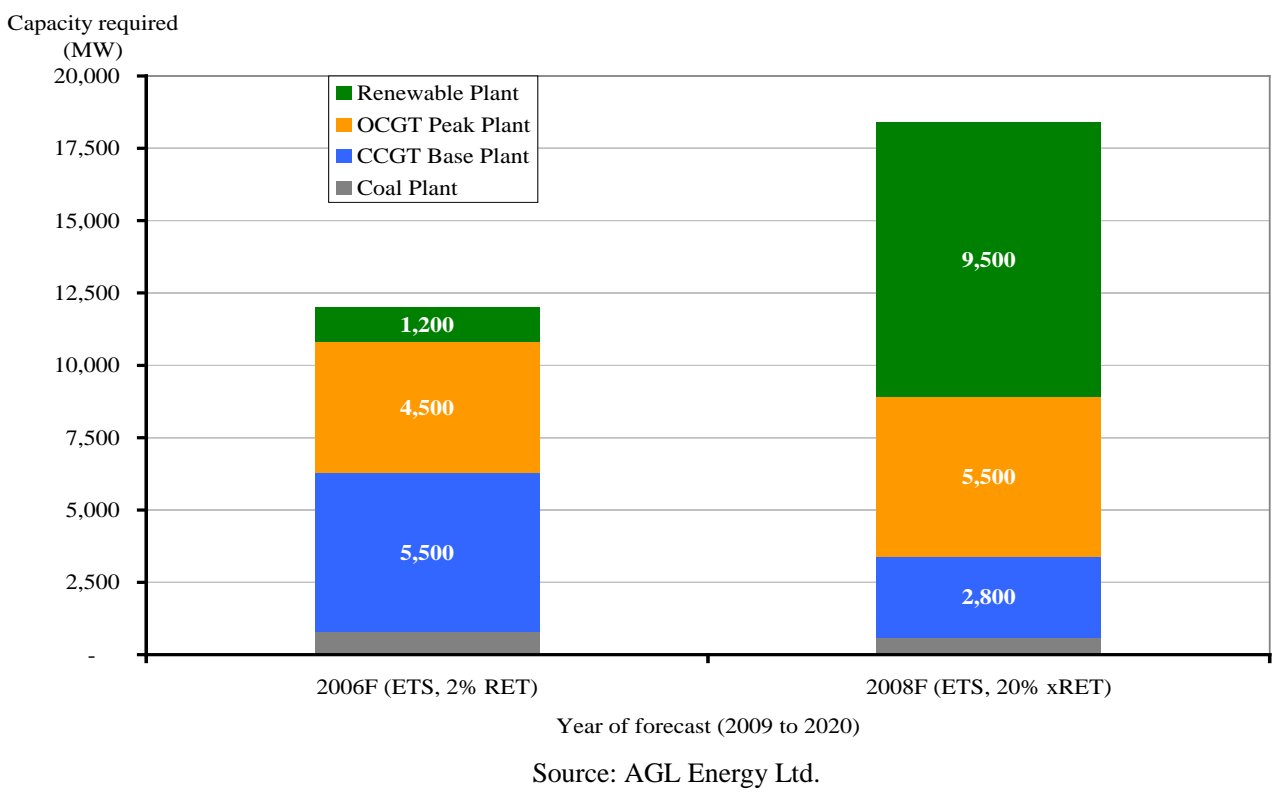

Note the large reduction in CCGT base plant; from 5500MW in the 2006F to only 2800 in the $2008 \mathrm{~F}$, which has occurred due to a large expansion in forecast renewable plant, from $1200 \mathrm{MW}$ to $9500 \mathrm{MW}$. Of course, the investment task jumps from US $\$ 13.8$ billion in 2006F to US\$26 billion in $2008 \mathrm{~F}$. Whether by design or accident, this policy has certainly done much to sedate

\footnotetext{
${ }^{18}$ See VaasaETT, (2009), “2008 World Retail Energy Market Rankings”, $4^{\text {th }}$ Edition.
} 
the worst potential effects of a base load dilemma, and thus ironically represents a good base-load bridging policy as a result. Going forward, the passage of time should start to make clear what the LNG net-back price of gas will actually be, and of course, what the ETS will actually look like and at least a medium term outlook for carbon price with a (short) history of carbon prices to work from. Ultimately, firms will need to navigate this complexity until the base load investment trajectory becomes clear. I expect to see an ongoing surge in OCGT plant investments until then, thus leading to a most unusual situation for the resource-rich Australian economy, an undercapitalised power grid with system structural imbalances looking the exact opposite to Table 2 above, that is, being overweight peaking plant and underweight base plant.

Finally on base load, Australia's wealth of resources also extend to uranium. Apart from some of the lowest cost coal and gas resources around the globe, and world class wind and solar resources, Australia also houses $38.2 \%$ of the world's known uranium reserves (and 100\% of OECD reserves) and is a major exporter. ${ }^{19}$ Yet nuclear power investments in Australia are prohibited. While it remains a deeply divisive issue, it would seem sensible to open the debate on this well proven technology to ensure it at least becomes an option over the longer term. Of course, the vast capital cost of a nuclear fleet would compound Australia's reliance on foreign capital.

\section{7. $\quad$ References}

Besser, J., Farr, J. and Tierney, S. (2002), “The political economy of long-term generation adequacy: why an ICAP mechanism is needed as part of standard market design”, Electricity Journal, 15(7): 53-62.

Bidwell, M. and Henney, A. (2004), “Will Neta ensure generation adequacy?”, Power UK, Issue 122, April 2004.

Bushnell, J. (2005), “Electricity resource adequacy: matching policies and goals”, Electricity Journal, 18(8): 11-21.

Cornell, A. and Drummond, M. (2009), "Reliance on foreign debt”, Australian Financial Review, 6 August 2009, p60.

EAA: Energy Alliance of Australia, (2009), "Financing the Australian Energy Sector 2009”, EAA Publication, Sydney.

Edison Electric Institute (2009), “The financial crisis and its impact on the Electric Utility Industry”, EEI Publication, Washington DC.

Neuhoff, K. and De Vries, L. (2004), “Insufficient incentives for investment in electricity generation”, CMI Working Paper 42, Cambridge.

Oren, S. (2003), "Ensuring generation adequacy in competitive electricity markets”, University of California Energy Institute - Energy Policy \& Economics 007, University of California, Berkley.

Peluchon, B. (2003), "Is investment in peak generation assets efficient in a deregulated electricity sector?”, Research Symposium: European Electricity Markets, The Hague, September 2003.

Roques, F., Newbery, D. and Nuttall, W. (2005), "Investment incentives and electricity market design: the British experience”, Review of Network Economics, 4(2): 93-127.

\footnotetext{
${ }^{19}$ Source: Geoscience Australia, http://www.ga.gov.au/minerals/exploration/resources advice/Table1_AIMR09.jsp
} 
Samuelson, R. (2009), “Economists ignored history”, Australian Financial Review, 6 July 2009, p.55.

Simshauser, P. (2005), "The gains from the microeconomic reform of the power generation industry in east-coast Australia”, Economic Analysis and Policy, 35(1\&2): 23-43.

Simshauser, P. (2008), "The dynamic efficiency gains from introducing capacity payments in the national electricity market”, Australian Economic Review, 41(4): 349-370.

Simshauser, P. (2009), “On emissions trading, toxic debt and the Australian power market”, Electricity Journal, Vol.22, No. 2, pp 9-29.

Simshauser, P., Molyneux, E. and Shepherd, M. (2010), “The entry cost shock and the re-rating of power prices in New South Wales”, Australian Economic Review, Vol.43, in-press.

Wen, F., Wu, F. and Ni, Y. (2004), "Generation capacity adequacy in the competitive electricity market environment”, Electrical Power \& Energy Systems, 26(2004): 365-372.

APPENDIX I - OECD GDP Growth (Year to June Qtr 2009)

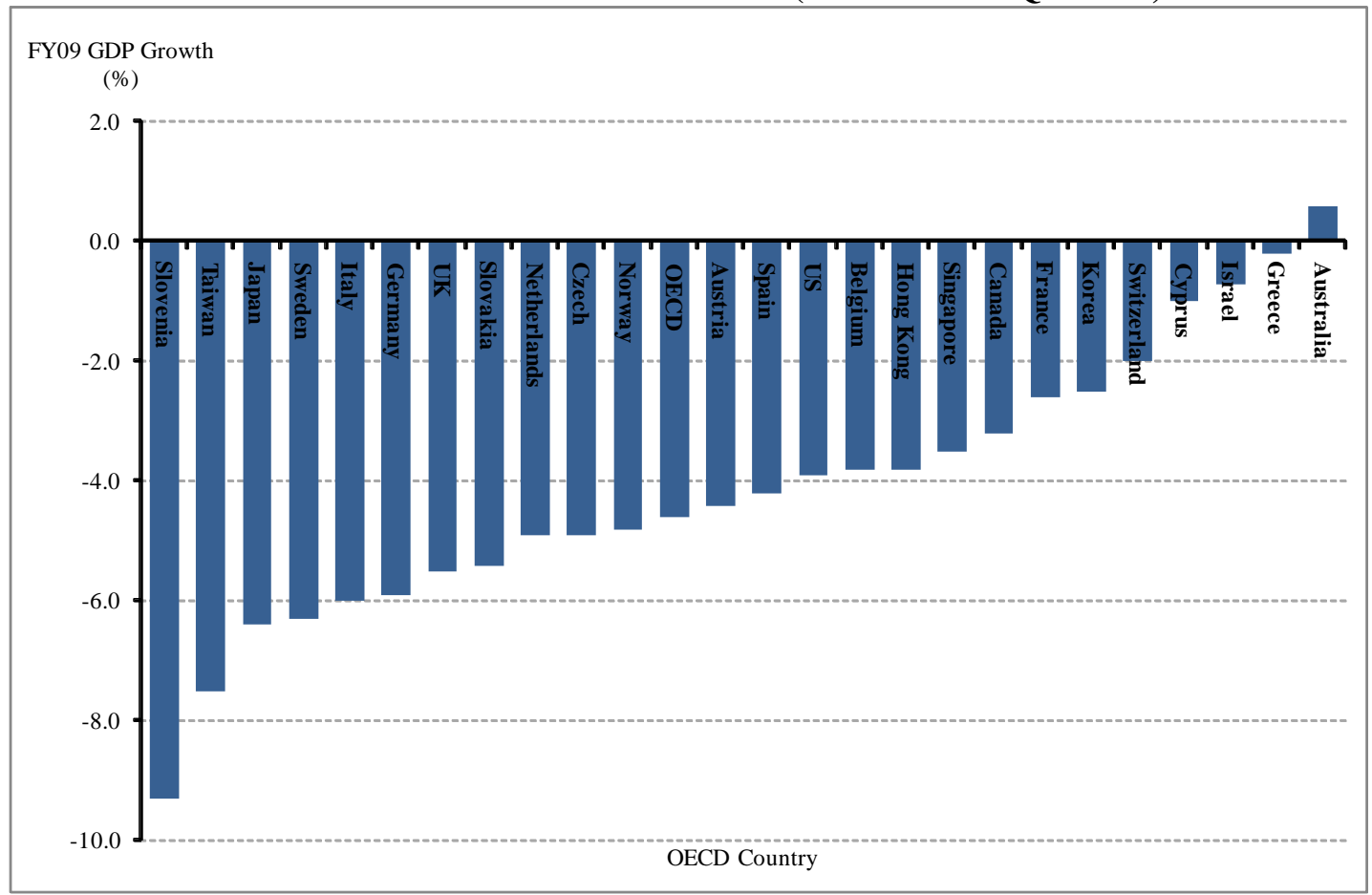

Source: ABS, IMF. 